\title{
Mineral tracers of the alongshore sediment transport (example from the South-Eastern Baltic Sea)
}

\author{
A. $\operatorname{Krek}^{1}$ and M. Ulyanova ${ }^{1,2}$
}

Received 22 March 2020; accepted 28 April 2020; published 19 October 2020.

The alongshore sediment transport plays a key role in the development of the coastal zone of the Sambia Peninsula, the Curonian, and Vistula (Baltic) spits of the South-Eastern Baltic Sea. One of the considerable indicators of the general direction of sediment transport is natural minerals-tracers, for example, glauconite. The distribution of glauconite in the upper layer of sediments marks the direction and intensity of the transport of suspended sediments, and, consequently, determines the boundary of the coastal lithodynamic system. Paleogene deposits are the only known source of glauconite on the coast of the Kaliningrad region which outcrops at the Sambia Peninsula. The grain size, morphological and mineralogical analyses of the bottom sediments were done. KEYWORDS: Glauconite; coastal lithodynamic system; accumulation dynamics; mineralogical analyses.

Citation: Krek, A. and M. Ulyanova (2020), Mineral tracers of the alongshore sediment transport (example from the South-Eastern Baltic Sea), Russ. J. Earth. Sci., 20, ES6003, doi:10.2205/2020ES000714.

\section{Introduction}

The alongshore sediment transport plays a key role in the development of the coastal zone of the Sambia Peninsula, the Curonian, and Vistula spits [Zenkovich, 1962]. Existing approaches in assessing the direction of the alongshore sediment transport are based on the calculation of the characteristics of active hydrodynamic factors against the background of the morphology of the coastal zone [Bogdanov et al., 1989, Boynagryan, 1966, Knaps, 1952; Kirlys, 1971; Krek et al., 2016: Leont'yev, 2015, Leont'yev et al., 1989, Shuisky, 1969; Shuisky et al., 1970 Soomere and Viška, 2014.

In most studies, calculations of bed load migration are based on the data of the network of the me-

\footnotetext{
${ }^{1}$ Shirshov Institute of Oceanology RAS, Moscow, Russia

${ }^{2}$ Immanuel Kant Baltic Federal University, Kaliningrad, Russia
}

Copyright 2020 by the Geophysical Center RAS. http://rjes.wdcb.ru/doi/2020ES000714-res.html teorological stations or simulated wind fields over different time intervals. This leads to a significant discrepancy in the results. The approach based on grain size distributions in sands [Gao and Collins, 2001. Kovaleva et al., 2016, Mc Laren and Bowles, 1985. Poizot et al., 2008 usually is used to reveal the general direction of sediment transport. However, some authors agree in part or disagree with the sediment trend analysis technique [Mc Laren et al., 2007. The study of numerically simulated potential alongshore sediment transport was done for the eastern Baltic Sea [Viška and Soomere, 2013. The stationary measurements of bottom currents also provide data on sediment transport [Babakov and Chubarenko, 2019.

Indisputable indicator of the general direction of sediment transport is natural mineralstracers, for example, glauconite. Some authors use the term "glaucony" [Banerjee et al., 2016. Odin and Létolle, 1980 or "glauconitic minerals" [Odin and Matter, 1981]. In this paper, we will use the term "glauconite" only. Glauconite is a potassium- and iron-rich dioctahe- 
dral sheet silicate with the general formula of $(\mathrm{K}, \mathrm{Na}, \mathrm{Ca})(\mathrm{Fe}, \mathrm{Al}, \mathrm{Mg}, \mathrm{Mn})_{2}(\mathrm{Si}, \mathrm{Al})_{4} \mathrm{O}_{10}(\mathrm{OH})_{2}$. The glauconite occurs on the coasts of the Baltic Sea: the Bornholm island [Clemmensen et al., 2011], Lithuania [Kairyté et al., 2005, west Estonian islands and western Estonia mainland [Mens et al., 1999], Kaliningrad region (Russia) [Emelyanov and Trimonis, 1981. The distribution of glauconite on the surface of the bottom (in the upper layer of sediments) marks the direction and intensity of the transport of suspended sediments, and, consequently, determines the boundary of the coastal lithodynamic system. In previous studies, the coastal zone, namely, the underwater coastal slope of the Sambia Peninsula and the root of the Curonian Spit, was taken as the source of the receipt of glauconite into the sediments of the Gdansk Basin [Blazhchishin and Usonis, 1970 Emelyanov, 1998].

Due to climate change, there is a redistribution of sediment transport forces [Babakov, 2003, Krek et al., 2016 and changes in the alongshore transport of the material. Previous mineralogical studies for the region date back to the second half of the 20 th century (no later than the 90s) and do not reflect the changing modern lithodynamic processes. A feature of this study is the sediment sampling under hydrometeorological conditions common for the entire coast, which avoids the imposition of the effects of changing wave conditions on the distribution of the tracer within the same lithodynamic system. Such work in this region has not been carried out. The presence of glauconite in sediments indicates their lithodynamic relationship with the source of the mineral, and a change in its concentration in the morphological elements of the coast shows the features of the last significant hydrodynamic activity, provided there are no additional sources. The study aimed to determine the spatial boundaries of the lithodynamic system using the mineral tracer (glauconite) of the alongshore transport of sediment.

\section{Study Area}

The research area included the South-Eastern Baltic Sea coast (Russian part) from the shoreline to a depth of $15 \mathrm{~m}$ and is divided to three geographical objects: the Sambia Peninsula $(74 \mathrm{~km}$ long), the northern part of the Vistula Spit (35 km long) and the southern part Curonian Spit (49 km long) Figure 1, see also the supplement data [Krek, Ulyanova, 2020, Table 1]). The Sambia Peninsula is a practically rectangular ledge of the land in the sea. The main dynamic process within the coastal zone of the Sambia Peninsula is the erosion with rate ranges from 0.1 to $0.7 \mathrm{~m} /$ year at capes to $0.6-1.5 \mathrm{~m} /$ year [Zhindarev et al., 2012]. The Curonian and Vistula spits are large accumulative bodies. The Curonian Spit is the longest $(98 \mathrm{~km})$ coastal barrier of the Baltic Sea. The coastline at the root of the Curonian Spit retreats at an average of $1.7 \mathrm{~m}$ /year [Badyukova and Solovjeva, 2015, in the central part the coast becomes stable [Petrov, 2010 . In the northern part of the Vistula Spit erosion processes also predominate, changing to accumulative ones in the middle part.

Southwestern and western winds dominate in the wind field in the Southeastern Baltic Sea; their velocity increases in cold seasons as determined by general atmospheric circulation and the geographic properties of the region [Bobykina and Stont, 2015]. The average monthly wind speed in the period from October to April exceeds 5-7 m/s, from May to September decreases to $3-5 \mathrm{~m} / \mathrm{s}$ [Dubravin and Stont, 2012. The average height of the coastal wave is $0.65 \mathrm{~m}$ [Pupienis et al., 2013], reaching $5 \mathrm{~m}$ during strong storms [Ambrosimov et al., 2013]. The rates of storm currents are sufficient for the massive movement of gravel-pebble material in the near shoreline zone and quartz sands seaward the underwater bars (up to $3.5 \mathrm{~m} / \mathrm{s}$ ). The maximal transport effect has a wave height of $2 \mathrm{~m}$. The emerged part of the beach is occasionally flooded under the influence of swell-induced conditions, especially during storm surges, which typically rise to 1-2 $\mathrm{m}$ above the annual mean sea level on the southern Baltic coast [Kapinski and Ostrowski, 2012 .

\section{Geological Setting}

The underwater coastal slope of the Kaliningrad region is almost everywhere composed of Quaternary sediments of various glacial stages as well as fluvioglacial, with a maximum thickness of 50$60 \mathrm{~m}$. Quaternary formations occur on a strongly eroded pre-Quaternary surface [Blazhchishin, 1998 , Emelyanov, 2002. Petrov, 2010. Moraine deposits 
are represented by sandy loam and loam with gravel and pebble inclusions, interglacial by various grained sands, often with gravel-pebble interlayers.

Quaternary sediments within the Russian area of the south-eastern Baltic Sea are underlain mainly by the Mesozoic rocks, especially the Cretaceous. Around Sambia Peninsula these Cretaceous bedrocks are sometimes outcropped at the bottom surface and accordingly can be a source of detrital material. Sediments in the southeastern part of the Baltic Sea consist mainly of quartz, feldspars, mica, and carbonates. Fine-grained fractions also contain glauconite and other clay minerals [Blazhchishin, 1976.

\section{The Glauconitic Deposits}

The outcrops of pre-Quaternary deposits on the erosion surface are rather limited and localized within the coastal bench and underwater coastal slope of the Sambia Peninsula [Dodonov et al., 1976. Eocene deposits are represented by a stratum of different-grained glauconitic-quartz sands cemented with iron hydroxides ("krant" facies). The Neogene formations, lying on the Eocene deposits, are represented by different grain size sands with interlayers of clays [Blazhchishin et al., 1978].

Paleogene deposits are the only known source of glauconite on the coast of the Kaliningrad region, which outcrops at the Sambia Peninsula. The absolute age of glauconite by the Palvesk Formation was 34.6 $\pm 3 \mathrm{Ma}$ [Kaplan et al., 1977], in later studies the range is $38.1 \pm 1.4$ and $38.8 \pm 1.2 \mathrm{Ma}$, which is much older than the dating obtained earlier [Ritzkowski, 1997]. The "Blue earth" of amber mining quarry at Yantarny on the Sambia Peninsula has glauconite concentrations up to $48 \%$ and $42 \%$ of the fine-sand and coarse-silt fractions, respectively [Blazhchishin, 1976, Blazhchishin and Usonis, 1970. Earlier studies of the southeastern Baltic Sea [Stauskaitè, 1962 show that the concentration of this mineral reaches its maximum at the Sambia Peninsula. The detrital origin of glauconite is consistent with the assumption that authigenic marine glauconite requires slow rates of sediment accumulation [Pettijohn, 1975], usually at depths more than $30 \mathrm{~m}$.

On the north coast, eastward the city of Svetlogorsk (see Figure 1), glacial and modern marine deposits, composed mainly of well-sorted sands, are subjected to wave processing. Dense clay, located on the bottom surface offshore the Curonian Spit, is transformed mud of the relic lagoon (Curonian Lagoon) [Dorokhov et al., 2017, Zhamojda et al., 2009 .

\section{Materials and Methods}

\section{Sampling}

Bottom sediments (66 samples) from the underwater coastal slope were sampled by the Van Veen grab on transverse profiles at depths of 5 , 10 and $15 \mathrm{~m}$, as well as from the swash zone Figure 1, see also the supplement data [Krek, Ulyanova, 2020. Table 1]). Sampling was done in the same hydrometeorological situations (longterm domination of anticyclonic conditions with moderate winds of eastern rhumb) for the western and northern coasts on 27 September 2017, and 1 October 2017, respectively. This lets to avoid imposing a mutually directed influence on the distribution of sediments of significant coastal hydrodynamic processes. Samples 37005 and 37007 were taken on 24 October 2017 (eastern rhumb breeze) at depth of 13 and $17 \mathrm{~m}$, respectively, during the 37th cruise of R/V Akademik Nikolaj Strakhov [Krek et al., 2019].

\section{Laboratory Analysis}

Mineralogical analysis. The weights were divided into heavy and light subfractions by immersing the detrital grains in the bromoform (liquid with a density of $2.899 \mathrm{~g} / \mathrm{cm}^{3}$ ). Minerals with a density higher than the bromoform's precipitated, and minerals with a density less than the density of the liquid floated to the surface. After the separation, the minerals were washed with a solvent and dried.

The selection of the main fraction was confirmed by counting the percentage of glauconite in bulk samples without grain-size separation and a similar calculation for the main fraction. The main fraction was a fraction of $0.063 \mathrm{~mm}$ [Skiba et al., 2014 . 


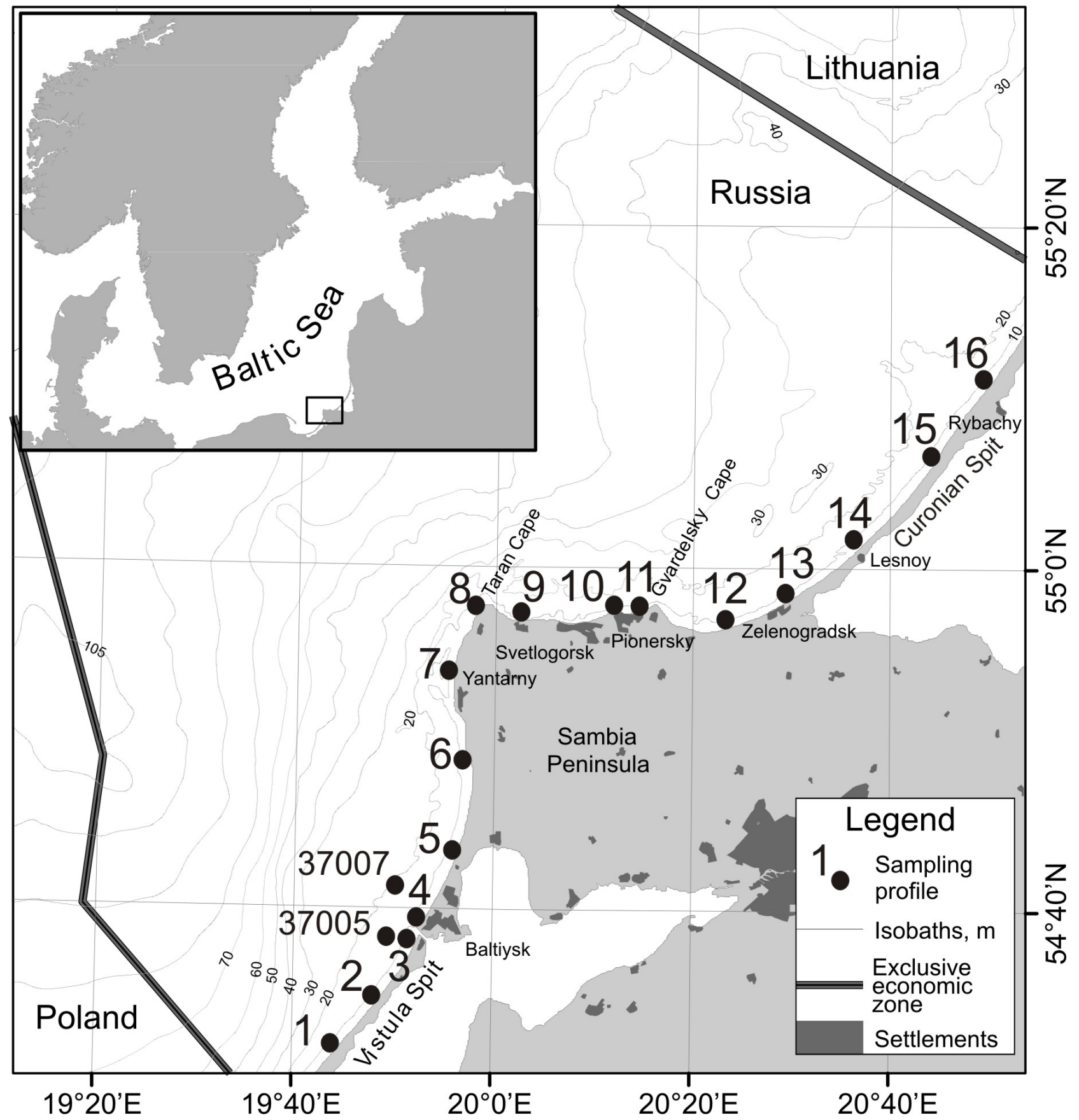

Figure 1. Study area and location of the sampling profiles. Each profile (point) included 4 samples at $0,5,10$, and $15 \mathrm{~m}$ depth. The coordinates of the points are given in the supplement data [Krek, Ulyanova, 2020, Table 1].

Mineral composition analysis in gross samples without division into subfractions was done for 18 samples, with division into heavy and light subfractions -27 samples, selective comparison of the content of glauconite in the gross sample and in the fractions - for 15 samples, see also the supplement data [Krek, Ulyanova, 2020, Table 1]).
Grain size, form, and roundness. The grain-size analysis (66 samples) was carried out by the sieve scattering method using vibratory sieve shaker Analysette 3 (Fritsch, Germany). When sieving, the Krumbein phi scale [Krumbein, 1934] was used with the following sieves: $4.0 ; 2.8 ; 2.0$; $1.4 ; 1.0 ; 0.71 ; 0.5 ; 0.355 ; 0.25 ; 0.18 ; 0.125 ; 0.09$; 

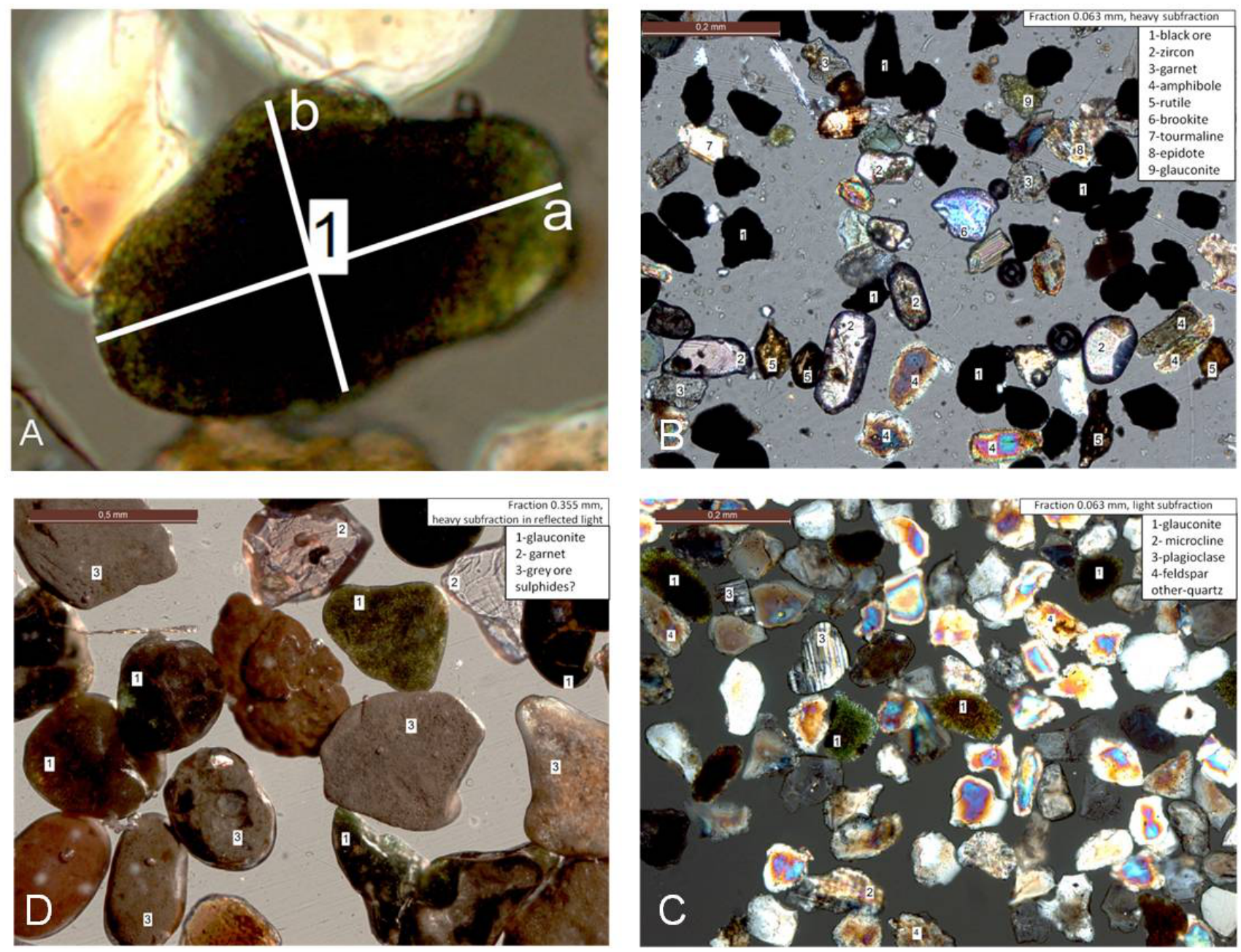

Figure 2. A - Morphometric characteristics of glauconite grain: a - longitudinal section (the major axis), b - cross-section (intermediate axis); $\mathrm{B}$ - glauconite in the heavy subfraction of the in bottom sediments in the fraction $0.063 \mathrm{~mm}$ on the profile 5 , at depth $15 \mathrm{~m}$; C - glauconite in the light subfraction of the in bottom sediments in the fraction $0.063 \mathrm{~mm}$ on the profile 5 , at depth $15 \mathrm{~m}$; D - glauconite in heavy subfraction $0.355 \mathrm{~mm}$ fraction on profile 1 , depth $15 \mathrm{~m}$ (yield of heavy subfraction $1.2 \%$, glauconite content $35.7 \%$, with its content in the light fraction $2.1 \%$ ).

and $0.063 \mathrm{~mm}$. The fraction of $0.063-0.09 \mathrm{~mm}$ was taken for the mineralogical analysis; in case of its absence, especially in well-sorted beach sands, the lowest sieved fraction (as usually 0.125 or $0.18 \mathrm{~mm}$ ) was used.

Morphological characteristics were studied by the $2 \mathrm{D}$ image analysis and a visual assessment of the roundness using polarizing microscope LEICA DM 2500 P. 162 grains from 29 samples were analyzed:
127 grains from the fraction $0.063-0.09 \mathrm{~mm}, 23$ grains from the fraction $0.125-0.18 \mathrm{~mm}, 12$ grains from fraction $0.18-0.25 \mathrm{~mm}$. In $2 \mathrm{D}$ image analysis the particle is assumed to lay over its more stable axis (the longest axis lies more or less parallel to the surface while the shortest axis is perpendicular) (Figure 2a) [Hawkins, 1993. For heavy minerals was the assessment of the grain roundness by [Rodríguez et al., 2013]. 
Table 1. The Roundness of Glauconite Grains by Coastal Regions ( $\mathrm{a}$ - the major axis, $\mathrm{b}$ - intermediate axis, see Figure 2a)

\begin{tabular}{cccccc}
\hline $\begin{array}{c}\text { Area/ } \\
\text { Morphometry }\end{array}$ & $\begin{array}{c}\text { Vistula Spit } \\
\text { (profiles 1-4) }\end{array}$ & $\begin{array}{c}\text { Sambia western coast } \\
\text { (profiles 5-8) }\end{array}$ & $\begin{array}{c}\text { Sambia northern coast } \\
\text { (profiles 9-12) }\end{array}$ & $\begin{array}{c}\text { Curonian Spit } \\
\text { (profiles 13-16) }\end{array}$ \\
\hline a/b & $\min$ & 1 & 1 & 0.89 & 1.04 \\
& $\max$ & 1.8 & 2.4 & 3.63 & 1.92 \\
$\operatorname{mean}$ & 1.37 & 1.47 & 1.51 & 1.41 \\
& $\sigma$ & 0.25 & 0.36 & 0.45 & 0.26 \\
\hline
\end{tabular}

\section{Results}

\section{Grain Size and Mineralogical Composition of Sediments}

Bottom sediments were mainly represented by fine- and medium-grained sands with a decrease in grain size in the direction towards the Curonian and Vistula spits. Coarse-grained sediments and boulders were adjacent to the erosion areas of the underwater coastal slope of the Sambia Peninsula and the root of the Curonian Spit. The sandy material of the beaches was characterized by good sorting and almost no fraction $<0.063 \mathrm{~mm}$. The grain size analysis data is given in Figure 1, see also the supplement data [Krek, Ulyanova, 2020, Table 2]).

The result of mineralogical analysis in different fractions revealed a very high correlation for minerals with the main grain size of $<0.063 \mathrm{~mm}$ and minerals in the total sample $(r=0.99)$ both for heavy and light subfractions. For larger grains, the correlation coefficient was still very high for light subfraction and decreased with increasing grain for heavy one $(<0.18 \mathrm{~mm}: r=0.97 ;<0.355 \mathrm{~mm}$ : $r=0.90)$.

Quartz (73\%), feldspars (7.1\%), glauconite $(6.4 \%)$ prevailed among light minerals, and black ore $(6.3 \%)$ among heavy ones. (Figure 1, see also the supplement data [Krek, Ulyanova, 2020, Table 3]). As admixtures there were garnet, zircon, carbonates, amphibole, epidote, zoisite, leucoxene, rutile, disthene, pyroxene, apatite, clay aggregates and mica (all less than $2 \%$; are listed in descending order). Sphen was discovered only once. Glauconite presented in almost all samples of bed load sediment and was typical for light subfraction, although it was found in heavy one (Figure $2 \mathrm{~b}$, Fig- ure 2 c). The crystalline bedrocks of the Scandinavian Peninsula are the initial source of some minerals of sand which came to the recent sediments from the eroded glacial deposits [Petrov, 2010. However, glauconite comes from the Paleogene and Neogene-Paleogene local deposits of Sambia Peninsula.

Another feature of the glauconite distribution was its higher content in larger fractions of heavy subfraction. The samples of grain size 0.18$0.355 \mathrm{~mm}$ contained $18-79 \%$ glauconite, but the yield of heavy subfraction from the total sample was about $1 \%$. Together with the homogeneous distribution in the light subfraction it did not make any appreciable deviations in its total content for the sample (Figure 2d).

\section{Morphometry of Glauconite Grains}

The ratio of the grain's major/intermediate axes in different lithodynamic areas was higher for the abrasive part of the coast (Sambia Peninsula). On the spits the grains were more rounded, which was due to higher erosion due to a longer stay in the processing zone (Table 1). Significant differences in the morphology of grains were observed along with profile from the beach to the depth. The grains were more rounded at depths of 5-10 m (Table 2).

\section{Distribution of Glauconite Along the Coast of the Kaliningrad Region}

Western coast. The band of the high content of glauconite (more than 5\%) extends along the western coast of the Sambia Peninsula, snuggling up to the shore. The maximum bulk glauconite content was revealed on the profile 6 to the south 

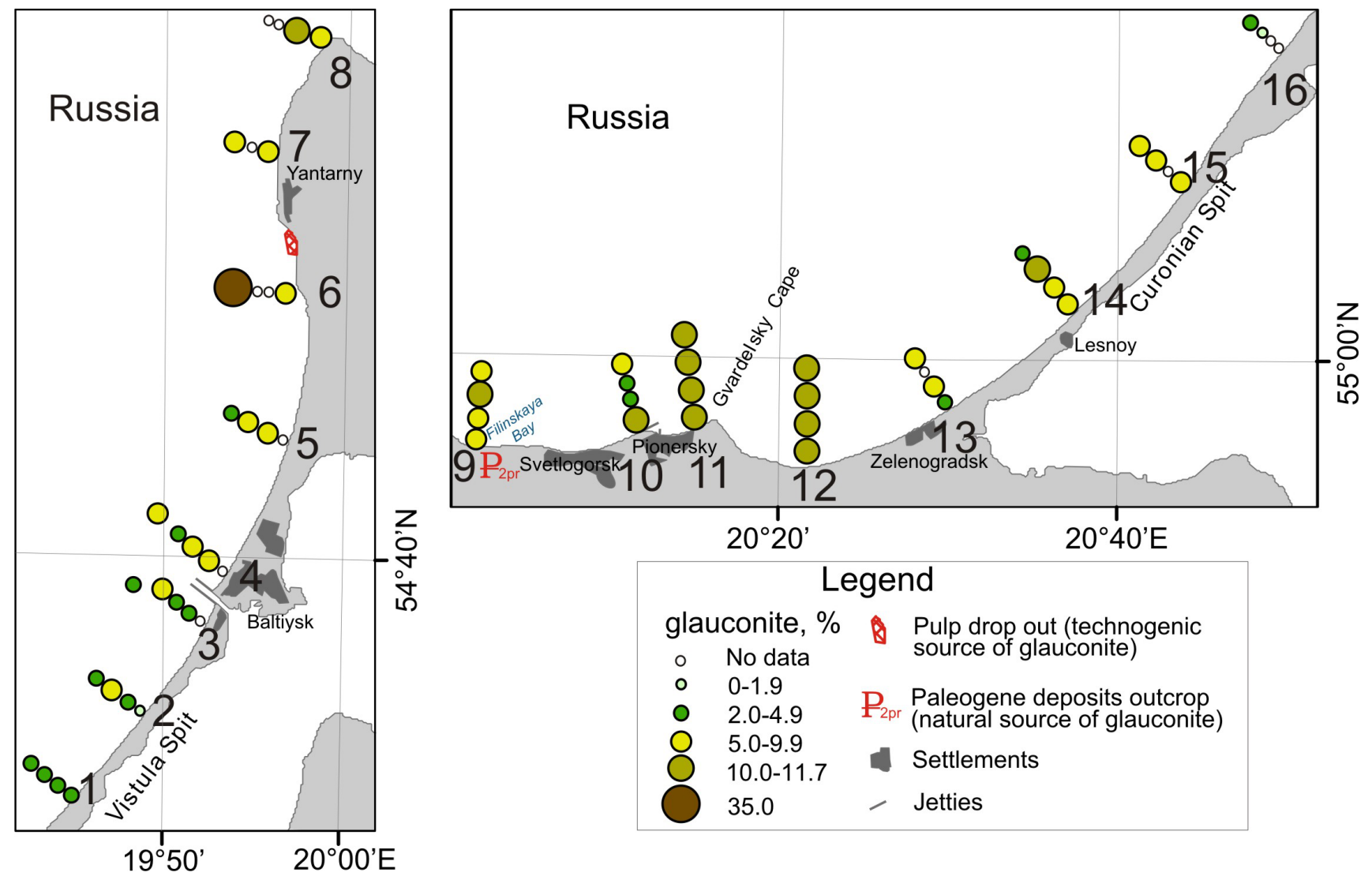

Figure 3. Distribution of glauconite on beaches and in bottom sediments along the coast of the Kaliningrad Region: A) western coast, B) northern coast. The points at each profile correspond to sampling depths of $0,5,10$, and $15 \mathrm{~m}$. The true location of samples is given in [Krek, Ulyanova, 2020, Table 1].

Table 2. The Roundness of Glauconite Grains by Depth

\begin{tabular}{|c|c|c|c|c|c|}
\hline \multicolumn{2}{|c|}{$\begin{array}{c}\text { Depth, m/ } \\
\text { Morphometry }\end{array}$} & 0 & 5 & 10 & 15 \\
\hline \multirow[t]{4}{*}{$\mathrm{a} / \mathrm{b}$} & $\min$ & 1.05 & 1.04 & 0.89 & 1 \\
\hline & $\max$ & 2.16 & 1.93 & 3 & 3.63 \\
\hline & mean & 1.54 & 1.39 & 1.42 & 1.55 \\
\hline & $\sigma$ & 0.31 & 0.34 & 0.35 & 0.48 \\
\hline
\end{tabular}

of the Yantarny settlement $(21.8 \%)$ (Figure 3a). This profile is characterized by a sharp change in lithodynamic conditions, where sand material from the beach, bypassing the depths of $5-10 \mathrm{~m}$, is deposited in the area of $15 \mathrm{~m}$ isobaths. In general, the content of glauconite decreased with distance from the source, reaching a minimum at a depth of $15 \mathrm{~m}$ of profile $1(1.6 \%)$. In the middle part of the Vistula Spit the tracer content significantly de- creases and does not exceed the maximum value of $3.4 \%$ (profile 1 , depth $5 \mathrm{~m}$ ).

Northern coast. The maximum content of glauconite was found near its source on profile 9 in the Filinskaya Bay and in the bay near the port of Pionersky (profile 11), where accumulative conditions arise, including those related to the operation of jetties. High content was obtained in the bays adjacent to the largest cape of the northern coast - Gvardeisky Cape. Partial discharge of the alongshore sediment flow takes place here. The capes were characterized by much lower levels. In general, the content of glauconite decreased in the direction of the middle of the Curonian Spit (Figure $3 \mathrm{~b}$ ). 


\section{Discussion}

The main mechanism for the spreading of sedimentary material (including glauconite) along the coast is the energy that occurs during the wave activity [Aybulatov, 1990, Knaps, 1952, Kos'yan and Pykhov, 1991; Leont'yev, 1987. Longo et al., 2002. Zaromskis and Gulbinskas, 2010. The maximum energy of the wave action occurs in the wave breaking zone, to which the maximum velocities of the currents are associated, mobilizing the sedimentary material [Tokpohozin et al., 2015]. According to full-scale measurements of currents and wave heights on the coast of the Sambia Peninsula in 1987-1991 [Babakov, 2003 such a zone with strong waves (wave height $3 \mathrm{~m}$ ) corresponded to a $5 \mathrm{~m}$ isobath. The roundness of the grains at similar depths (see Table 2) marks this zone. Differentiation of grains occurs by depth.

As glauconite is an unstable mineral [Blazhchishin and Usonis, 1970, Berger, 1986] it has been suggested that grain's morphology changes moving along the shore in the sediment flow off its source. However, such a relationship was not revealed. The absence of significant shape changes (mean $0.09 \mathrm{~mm}$ - the major axis, $0.06 \mathrm{~mm}$ - intermediate axis for each of the sites), no debris and the identical roundness of grains along the coast, is probably due to the similar time of grain exist in the corresponding hydrodynamic situation. Migration of grains along the coast can be multidirectional and multiphase, and the presence of glauconite in remote areas indicates the final deposit of sediments. The main factor in the differentiation and destruction of grains is the transverse shifts of the deposits in the surf zone.

\section{Western Coast}

A feature of the western coast is the activity of the amber combine. Overburden rocks, including glauconite-rich Paleogene sands, are discharged to the beach [Krek et al., 2018]. Being subjected to wave processing, sandy material is carried along the coast by coastal currents, forming wide beaches [Sivkov and Chubarenko, 1997]. Both with the outcropped Neogene-Paleogene deposits of the Sambia Peninsula, the economic activities make a key contribution to the delivery of glauconite on the west coast. There is also the possibility of an alongshore supply of technogenic material from the pulp discharge (originated by amber mining) [Krek et al., 2018. The presence of boulder blind in the top of the underwater coastal slope marks the active development of erosion processes. Similar zones of intensive bottom erosion were defined to the north of the Yantarny settlement (depths of 5 and $15 \mathrm{~m}$ ) and near Cape Taran (depths of 10-15 m). The alongshore sediment flow is depleted, and only traces of the predominant alongshore migration of the sediment appear here. The strong alongshore drift offshore Yantarny settlement and its' decreasing in approx. 5 times near Baltiysk was observed in a previous study [Ostrowski et al., 2012.

Special attention should be paid to the variability of the glauconite distribution near the jetties of the Baltiysk port. Transverse to the shore constructions usually make special hydrodynamic conditions (vortices) and interrupt single alongshore sediment flow [Pupienis et al., 2013] passing the sediment seaward [Z̆aromskis and Gulbinskas, 2010. The cessation of sediments supply for upcoast induces beach erosion downcoast of harbors [Komar, 1983, and thus bay formation [Lausman et al., 2010. However, both on the source side and on the "leeward" side of the jetties, the difference in glauconite content did not exceed $1.5 \%(6-7.5 \%$ northward and 5-6\% southward of the jetties). The decrease in glauconite content to the south of the jetty was typical for the coastal region, which is located in the wind-wave shadow (up to $3.7 \%$ of glauconite at a depth of $5 \mathrm{~m}$ ). Jetties impede alongshore sediment migration, initiating sediment accumulation on each side of the jetties [Babakov and Chubarenko, 2019. A similar influence of hydroengineering constructions at sediment transport is observed in the shady areas near the port facilities in Lithuania [Z̆aromskis and Gulbinskas, 2010. Jarmalavičius et al., 2012, Kriauciuniene et al., 2013.

Nevertheless, the mechanism for overcoming the sediment transport of fairway and near-channel depression (depths of 18-20 m), adjacent to the jetties end, is not clear now. The rounding of grains near the Vistula spit is higher than on the Western coast of the Sambia peninsula, which implies their longer presence in the wave-breaking zone. During storms, as a rule, the transverse transport of sediments predominates, which, apparently, carry sedimentary material to deeper areas and allow it to 
bend around bottom depression and piers deeper (at depths of 13-15 m) [Petrov, 2010]. The return of the material to the wave-surf zone takes a longer time, which is reflected in the roundness of the grains at the Vistula spit.

\section{Northern Coast}

On the northern coast the alongshore sediment flow starts from Cape Taran and can be traced to the Rybachy settlement, where it becomes noticeably weaker (glauconite content is 1.1 to $3.5 \%$ at depths of 5 and $10 \mathrm{~m}$, respectively). The increase in the content of glauconite in the bay westward the Cape Gvardeisky is caused by the deviation of the alongshore transport from the shore. This process is facilitated by the configuration of the bay shoreline and Pionersky port facilities. The direction of the northern jetty creates a deficit of sediment on the beaches of the middle part of the bay, where intensive erosion processes develop. On the contrary, a large accumulative body is developing more than $5 \mathrm{~m}$ isobaths and the fairway is sanding up.

A specific situation develops in the area of the Lesnoy settlement, where the anomaly of glauconite content arises at a depth of $10 \mathrm{~m}$ against the background of an obvious decrease in glauconite. Perhaps the transverse outflow of material plays a key role here as a result of the emergence of a local convergence zone of two counterflows of sediment [Krek et al., 2016]. In the descriptions of geological wells of the region, glauconite is noted in Paleogene and Upper Cretaceous deposits, as well as in marine deposits of the Middle Pleistocene [Dodonov et al., 1976. The thickness of the Quaternary sediments overlapping in the area of the village Lesnoy deposits of the Middle Pleistocene is up to $40 \mathrm{~m}$. Thus, the supply of glauconite from these deposits is unlikely.

Further, along the Lithuanian border, the alongshore component again prevails, down to the depletion of the current. In the coastal zone at profile 16 the mineralogical composition changes noticeably and ore black minerals (40.8\%), quartz $(28 \%)$, zircon $(9.9 \%)$, garnet $(7.5 \%)$ and grothite $(1.1 \%)$ dominate in the bulk fraction. The spit slope's sediments are characterized by an increase in the heavy subfraction of up to $22 \%$ (with an average for the coast of 10\%). For the coast of the Curonian Spit the areas for the formation of heavy mineral deposits were identified in previous studies [Boyna- gryan, 1966, as a result of prolonged wave processing of sediments in accumulation sites. A change in the composition of bottom sediments can be caused by both a change in the underlying surface and the result of prolonged wave processing and depletion of the sediment flow. On the underwater coastal slope of the spit, hydrodynamic processes transform and redistribute mainly only surface deposits. In the area of the village Rybachy (profile 16) peat layer outcrops on the underwater coastal slope, where, being destroyed by waves, it forms a ledge about $0.5 \mathrm{~m}$ high [Sergeev, 2015]. Separate outcrops of the roof of the layer are recorded in shallow water. The roof of the peat formation has a terraced surface, the steps of which are partially covered by sand deposits. In the basement of the underwater coastal ledge, moraine loams, underlying the peat layer, are exposed. These loams may contain only a small amount of glauconite, so these deposits cannot be considered as a source of glauconite.

In the Lithuanian underwater slope the glauconite is present from 0 until $30 \mathrm{~m}$ water depth. It was found in 20 of 37 samples of the fraction $<0.01 \mathrm{~mm}$ ranges from $0.7 \%$ to $4.7 \%$ (average $2.8 \%$ ) and once $(1.2 \%)$ in 17 samples of the fraction 0.01-0.063 mm [Kairyté et al., 2005]. It was interpreted as derived from the Sambia Peninsula sediments. The direction of glauconite transport is similar to the alongshore sediment transport [Trimonis and Stryuk, 2002 and glauconite has been observed up to $200 \mathrm{~km}$ north of Sambia Peninsula, indicating sediment transport along the coasts of the southeastern Baltic Sea [Blazhchishin, 1976. This leads to the conclusion that glauconite accumulates in the bottom sediment almost exclusively from the northward sediment supply from the abraded shores of the Sambia Peninsula to the south.

The background offshore points at depths of 45 and $30 \mathrm{~m}$ deserve special attention. The presence of glauconite in surface sediments (4.3 and $5.8 \%$ of the bulk sample, accordingly), as well as a similar mineralogical composition with the coastal zone, indicates lithodynamic activity.

\section{Borders of Alongshore Transport}

Reducing of the glauconite content in the sediments of the middle parts of the Vistula and Curo- 
nian spits does not indicate the boundary of the lithodynamic system functioning. Apparently, here, far from the source, the processes of wave processing and differentiation of sand deposits come to the fore, as evidenced by an increase in the content of heavy subfraction. Taking into account the receipt of additional sedimentary material as a result of the erosion of accumulative bodies and longer wave processing, minerals are sorted by their specific weight. Also, the total content of quartz in the sediments decreases in the middle parts of the spits, but this is an indirect tracer that only emphasizes the effect of wave processing of the sediments. Lighter minerals are carried further along the shore or to a depth. Such a process occurs with glauconite, as evidenced by studies on the underwater coastal slope of the Lithuanian area (on average, glauconite content of about $8 \%$ and a decrease in the quartz content) [Gaigalas et al., 1997 and mineralogical analysis of the deeper part of the shelf.

\section{Conclusion}

Glauconite in bottom sediments was discovered along the entire coast of the Kaliningrad region. The study of this mineral tracer distribution along the coast allowed us to determine the spatial boundaries of the alongshore transport of sediment. The maximum concentration of glauconite is naturally located near the source, i.e. near the Yantarny settlement. Tracking glauconite along the spits revealed the recharge alongshore transport from the Sambia Peninsula. Moreover, a noticeable decrease in the heavy subfraction in the spits sediments relative to the source (6.4\% on the Baltic Spit at $15.9 \%$ in the west of the Sambia Peninsula and $1.9 \%$ on the Curonian Spit at $3.4 \%$ in the north of the Sambia Peninsula) shows a relatively longer time that glauconite was located on the Baltic Spit outside the source. Such a process is associated with the action of jetties near Baltiysk located perpendicular to the coast. The receipt of material on the Baltic Spit is likely to occur much less frequently, but in a larger volume and is of a pulsed nature during extreme storms.

Local increases in the content of glauconite, apparently, are formed in zones of weakening sediment flow in the bays, or with local sediment trans- port. The withdrawal of material from the coastal zone is carried out in the emerging local storm zones of convergence due to the near-bottom compensation outflow. An example of such an outflow zone is the northern jetty of Baltiysk, where due to the construction the content of glauconite marks the outflow of material from the coast.

Acknowledgments. This work was supported by the state assignment of the Ministry of Science and Higher Education of the Russian Federation (theme number 0149-2019-0013). The referees and the editor are thanked for their critical comments that substantially improved the original manuscript.

\section{References}

Ambrosimov, A. K., I. M. Kabatchenko, et al. (2013), Seasonal characteristics of waves in the southeastern part of the Baltic Sea in 2008-2009, Russ. Meteorol. Hydrol., 38, No. 3, 191-198, Crossref

Aybulatov, N. A. (1990), Dynamics of Solid Matter in the Shelf Zone, Gidrometeoizdat, Leningrad. (in Russian)

Babakov, A. N. (2003), Spatio-temporal structure of currents and sediment migrations in the coastal zone of the south-eastern Baltic Sea (Sambia Peninsula and Curonian Spit). Doctoral thesis, KSU, Kaliningrad. (in Russian)

Babakov, A., B. Chubarenko (2019), The Structure of the net alongshore sediment transport in the Eastern Gulf of Gdansk, Water Resources, 46, No. 4, 515-529. Crossref

Badyukova, E. N., G. D. Solovieva (2015), Coastal eolian landforms and sea level fluctuations, Oceanol., 55, No. 1, 124-130, Crossref

Banerjee, S., U. Bansal, A. Thorat (2016), A review on palaeogeographic implications and temporal variation in glaucony composition, J. Palaeogeogr., 5, No. 1, 43-71, Crossref

Berger, M. G. (1986), Terrigenous Mineralogy, Nedra, Moscow. (in Russian)

Blazhchishin, A. I. (1976), Physical and geographical sketch of the catchment area A review on palaeogeographic implications and temporal variation in glaucony composition, Geology of the Baltic Sea (Gudelys V. K., Yemelyanov E. M. (Eds.) p. 117-130, Moxlas, Vilnius.

Blazhchishin, A. I. (1998), Paleogeography and Evolution of Late Quaternary Sedimentation in the Baltic Sea, Yantarny Skaz, Kaliningrad. (in Russian)

Blazhchishin, A. I., V. L. Boldyrev, K. V. Moroshkin (1978), Amber-bearing deposits of the Paleogene and conditions of their occurrence on the submerged slope of the Sambia Peninsula, Tectonics and Minerals of 
Belarus and the Baltic States, Orlenok V. V. (Ed.) p. 119-127, KSU, Kaliningrad. (in Russian)

Blazhchishin, A. I., M. M. Usonis (1970), Features of sedimentation in the southeastern part of the Baltic Sea according to mineralogical analysis, Baltica, 4, 115-144. (in Russian)

Bobykina, V. P., Zh. I. Stont (2015), Winter storm activity in 2011-2012 and its consequences for the Southeastern Baltic Coast, Water Resources, 42, No. 3, 371-377, Crossref

Bogdanov, N. A., V. A. Sovershaev, et al. (1989), Evolution of the knowledge on dynamics of the SouthEastern coasts of the Baltic Sea, Geomorphol., 2, 62-69. (in Russian)

Boynagryan, V. R. (1966), Morphometric analysis of the short-term changes of the coastal topography, Oceanol., 4, No. 4, 651-658. (in Russian)

Clemmensen, L. B., R. G. Bromley, P. M. Holm (2011), Glauconitic deposits at Julegård on the south coast of Bornholm, Denmark dated to the Cambrian, Bull. Geolog. Soc. of Denmark, 59, 1-12.

Dodonov, A. E., et al. (1976), The Newest Tectonics of the Southeastern Part of the Baltic syneclise, MSU Publishing House, Moscow. (in Russian)

Dorokhov, D., E. Dorokhova, V. Sivkov (2017), Marine landscape mapping of the south-eastern part of the Baltic Sea, Baltica, 30, No. 1, 15-22, Crossref

Dubravin, V. Ph., Zh. I. Stont (2012), Hydrometeorological regime, structure and circulation of the waters, Oil and Environment of the Kaliningrad Region. Vol. II: Sea, Sivkov V. V. (Ed.) p. 69-105, Terra Baltica, Kaliningrad. (in Russian)

Emelyanov, E. M. (2002), Geology of the Gdansk Basin, Baltic Sea, Yantarnyj Skaz, Kaliningrad.

Emelyanov, E. M. (1998), Barrier Zones in the Ocean. Sediment and Mineralization, Geoecology, Yantarnyj Skaz, Kaliningrad. (in Russian)

Emelyanov, E. M., $\quad$ E. S. Trimonis (1981), Mineralnyj sostav pozdnechetvertichnykh osadkov Baltijskogo morya po dannym rentgendifraktometricheskogo analiza, Osadkoobrazovanie v Baltijskom More, Lisitsyn A. P. and Emelyanov E. M. (Eds.) p. 180188, Nauka, Moscow. (in Russian)

Gao, S., M. Collins (2001), The use of grain size trends in marine sediment dynamics: A review, Chin. J. Oceanol. Limnol., 19, No. 3, 265-271, Crossref

Gaigalas, A., S. Gulbinskas, M. Melešyté (1997), Petrographical composition of the Pleistocene tills in the Lithuanian and south-west Latvian sea-side zone of the Baltic Sea, Geologia i Geomorfologia, 3, 7393.

Hawkins, A. E. (1993), The Shape of PowderParticle Outlines, Wiley, New York. Crossref

Jarmalavičius, D., G. Žilinskas, D. Pupienis (2012), Impact of Klaipèda port jetties reconstruction on adjacent sea coast dynamics, J. Environ. Eng. Landsc. Manag., 20, No. 3, 240-247, Crossref

Kairyté, M., R. Stevens, E. Trimonis (2005), Prove- nance of silt and clay within sandy deposits of the Lithuanian coastal zone (Baltic Sea), Mar. Geol., 218, 97-112, Crossref

Kapiński, J., R. Ostrowski (2012), Motion of water and sediment due to non-breaking waves in the swash zone, Oceanol., 54, No. 2, 175-197, Crossref

Kaplan, A. A., A. A. Grigialis, et al. (1977), Stratigraphy and correlation of Paleogene deposits of the southwest of the Baltic, Ofioliti, 4, 31-43.

Kirlys, V. I. (1971), Some features of the dynamics of the sea shores of the Kurshu-Neriai shoal, Tr. LitSSR, B.4, No. 67, 211-224. (in Russian)

Knaps, R. (1952), Ograditelnye sooruzhenya tipa molov i dvizhenye nanosov na peschanykh poberezhyakh, Izvestiya AN Latviyskoy SSR, 6, No. 59, 87130. (in Russian)

Komar, P. D., (Ed.) (1983), Coastal erosion in response to the construction of jetties and breakwaters, Handbook of Coast. Proc. Erosion p. 191-204, CRC Press Inc., Boca Raton, Florida.

Kos'yan, R. D., N. V. Pykhov (1991), Hydrogenous Sediment Shift in the Coastal Zone, Nauka, Moscow. (in Russian)

Kovaleva, O., B. Chubarenko, D. Pupienis (2016), Grain size variability as an indicator of sediment transport alongshore the Curonian Spit (south-eastern Baltic Sea), Baltica, 29, 145-155, Crossref

Krek, A., Zh. Stont, M. Ulyanova (2016), Alongshore bed load transport in the southeastern part of the Baltic Sea under changing hydrometeorological conditions: Recent decadal data, Region. Stud. Mar. Sci., 7, 81-87, Crossref

Krek, A. V., M. O. Ulyanova, E. S. Bubnova, et al. (2019), Geoecological conditions in The Baltic Sea in 2017, Oceanol., 59, No. 1, 167-169, Crossref

Krek, A., M. Ulyanova, S. Koschavets (2018), Influence of land-based Kaliningrad (Primorsky) amber mining on coastal zone, Mar. Pol. Bull., 131(Pt A), 1-9, Crossref

Krek, A., M. Ulyanova (2020), Mineral tracers of the alongshore sediment transport (Data supplement), Earth Science DataBase, GC RAS, Moscow. Crossref

Kriauciuniene, J., G. Zilinskas, et al. (2013), Impact of Šventoji port jetties on coastal dynamics of the Baltic Sea, J. Environ. Eng. Landsc. Manag., 21, 114-122, Crossref

Krumbein, W. C. (1934), Size Frequency Distribution of Sediments, J. Sediment. Petrol., 4, 65-77, Crossref

Lausman, R., A. H. F. Klein, M. J. F. Stive (2010), Uncertainty in the application of the parabolic bay shape equation: Part 2, Coast. Eng., 5\%, 142-151, Crossref

Leont'yev, O. K., L. A. Zhindarev, O. I. Ryabkova (1989), Origin and evolution of the large coastal accumulative forms, Theoretical Problems of the Sea Coasts Development p. 83-91, Nauka, Moscow. (in Russian) 
Leont'yev, I. O. (2015), Sediment fluxes along the south-eastern coast of the Baltic Sea, Geomorphol., 1, 70-76, Crossref

Leont'yev, I. O. (1987), On the coastal horizontal circulation of water in conditions of irregular waves, Water Res., 5, 16-22. (in Russian)

Longo, S., P. Marco, I. J. Losada (2002), Turbulence in the swash and surf zones: A review, Coast. Eng., 45, No. 3, 129-147, Crossref

McLaren, P., D. Bowles (1985), The effects of sediment transport on grain size distributions, $J$. Sediment. Petrol., 55, No. 4, 457-470, Crossref

McLaren, P., S. H. Hill, D. Bowles (2007), Deriving transport pathways in a sediment trend analysis (STA), Sediment. Geol., 202, No. 3, 489-498, Crossref

Mens, K., I. Paalits, I. Puura (1999), Biostratigraphic dating of pebbles from the Upper Cambrian conglomerates in Estonia, Proc. Estonian Acad. Sci., Geol., 48, 140-157.

Odin, G. S., R. Létolle (1980), Glauconitization and phosphatization environments: A tentative comparison, SEPM Special Publications, 29, 227-237, Crossref

Odin, G. S., A. Matter (1981), De Glauconiarum Origine, Sediment., 28, 611-641, Crossref

Ostrowski, R., Z. Pruszak, et al. (2012), Anthropogenic Effects on Coastal Sediment Fluxes in a Nontidal Gulf System, J. Waterway, Port, Coastal, Ocean Eng., 138, 491-500, Crossref

Petrov, O. V., (Ed.) (2010), Atlas of Geological and Environmental Geological Maps of the Russian Area of the Baltic Sea, VSEGEI, Saint Petersburg.

Pettijohn, F. J. (1975), Sedimentary Rocks (second ed.), Harper and Row Publishers, New York.

Poizot, E., Y. Méar, L. Biscara (2008), Sediment trend analysis through the variation of granulometric parameters: A review of theories and applications, Earth-Sci. Reviews, 86, 15-41, Crossref

Pupienis, D., S. Jonuškaité, et al. (2013), Proc 12 International Coastal Symposium (Plymouth, England), Conley D. C. et al. (Eds.), Klaipèda port jetties impact on the Baltic Sea shoreline dynamics, Lithuania, J. Coast. Res., 65, 2167-2172, Crossref

Ritzkowski, S. (1997), K-Ar Altersbestimmungen der Bernsteinführenden Sedimente des Samlandes (Paläogen, Bezirk Kaliningrad), Metalla, Sonderheft, 66, 19-24.

Rodríguez, J., T. Edeskär, S. Knutsson (2013), Particle shape quantities and measurement tecniques - A review, Electron. J. Geotechn. Eng., 18, 169.

Sergeev, A. Yu. (2015), History of geological development of the Curonian Spit in the Holocene and modern lithodynamic processes in the coastal area. Doctoral thesis, Earth Science DataBase, VSEGEI, St. Petersburg. (in Russian)

Shuisky, Yu. D. (1969), Peculiarities of the coastal-sea placers of the eastern Baltic due to the regime of the alongshore sediment transport. Dis. Cand. geogr. sci. (in 2 vol.), Earth Science DataBase, IO Acad. Sci USSR, Moscow. (in Russian)

Shuisky, Yu. D., V. L. Boldyrev, B. V. Kochetkov (1970), On the conditions and features of the formation of the coastal sea alluvial deposits of the eastern part of the Baltic Sea, DAN USSR, 194, No. 1, 187-190. (in Russian)

Sivkov, V., B. Chubarenko (1997), Influence of amber mining on the concentration and chemical composition of suspended sedimentary matter (Sambian Peninsula, Southeast Baltic), Mar. Georesour., Geotechnol., 15, No. 2, 115-126, Crossref

Skiba, M., K. Maj-Szeliga, et al. (2014), Weathering of glauconite in soils of temperate climate as exemplified by a Luvisol profile from Góra Puławska, Poland, Geoderma, 235-236, 212-226, Crossref

Soomere, T., M. Viška (2014), Simulated wavedriven sediment transport along the eastern coast of the Baltic Sea, J. Mar. Sys., 129, 96-105, Crossref

Stauskaitè, R. (1962), Baltijos pajürio kranto zonos Sventosios-Jantarnoje (Palvininkii) ruozo sméliit mineraloginé sudétis, Lietuvos TSR Moklsu Akademijos darbai. Serija B, 4, 83-106. (in Lithuanian)

Tokpohozin, N. B., B. Kounouhewa, et al. (2015), Modelling of sediment movement in the surf and swash zones, Acta Oceanol. Sinica, 34, No. 2, $137-$ 142, Crossref

Trimonis, E. S., V. L. Stryuk (2002), Sources of sedimentary matter, Geology of the Gdansk Basin, Emelyanov E. M. (Ed.) p. 75-78, Yantarny Skaz, Kaliningrad.

Viška, M., T. Soomere (2013), Simulated and observed reversals of wave-driven alongshore sediment transport at the eastern Baltic Sea coast, Baltica, 26, No. 2, 145-156, Crossref

Zaromskis, R., S. Gulbinskas (2010), Main patterns of coastal zone development of the Curonian Spit, Lithuania, Baltica, 23, No. 2, 149-156.

Zenkovich, V. P. (1962), Basis of Sea Coasts Development, USSR Acad. Sci., Moscow. (in Russian)

Zhamoida, V. A., D. V. Ryabchuk, et al. (2009), Recent sedimentation processes in the coastal zone of the Curonian Spit (Kaliningrad region, Baltic Sea), Z. dt. Ges. Geowiss, 160, 143-157, Crossref

Zhindarev, L. A., O. I. Ryabkova, V. Sivkov (2012), Coastal geology and geomorphology, Oil and Environment of the Kaliningrad Region. Vol. II: Sea, Sivkov V. V. et al. (Eds.) p. 19-36, Terra Baltica, Kaliningrad. (in Russian)

\section{Corresponding author:}

Marina Ulyanova, Shirshov Institute of Oceanology RAS, 36 Nakhimovsky Prospect, 117997 Moscow.

(marioches@mail.ru) 